\title{
Genetical analysis of the ability of the rice weevil Sitophilus oryzae (Coleoptera, Curculionidae) to breed on split peas
}

\author{
ANNE-MARIE GRENIER*, MBAILAO MBAIGUINAM \& BERNARD DELOBEL \\ Laboratoire de Biologie Appliquée, Bât. 406, I.N.S.A. - I.N.R.A., 20 Av. A. Einstein, F-69621 Villeurbanne Cedex, \\ France.
}

\begin{abstract}
Sitophilus weevils are mainly pests of cereals, but some populations of $S$. oryzae are able to feed and breed on split peas. Genetical analyses and resistance tests were individually conducted by crossing individuals of a pea-resistant strain from China with those of a pea-susceptible strain from the laboratory (SFr). Adults from parental populations and progenies from $F_{1}$ and $\mathrm{F}_{2}$ generations (two reciprocal crosses), as well as from backcrosses, were obtained on wheat and thereafter tested for their ability to survive on yellow split peas for 14 days. The expression of pea-resistance in $S$. oryzae is under simple Mendelian control implicating only one recessive and no sex-linked gene. Resistant populations able to develop on split peas are homozygous for the recessive gene, but some wild susceptible populations can contain heterozygous individuals at a very low frequency. The possible role of intracellular symbionts in pea detoxification was tested by comparing aposymbiotic and normally symbiotic populations. Symbionts were not directly required but might play a role in supplying disposable energy for the metabolism implicated in the detoxification of allelochemicals.
\end{abstract}

Keywords: detoxification, food plant preference, Insecta, legumes, Mendelian character, rice weevil, Sitophilus oryzae.

\section{Introduction}

Weevils from the genus Sitophilus (Coleoptera, Curculionidae) can be considered as major pests of stored cereals all over the world. Although the three main Sitophilus species are mostly specific to cereals, some strains of $S$. oryzae $(\mathrm{L}$.), the rice weevil, are able to feed and breed on split peas; the two other species, $S$. zeamais Motsch., the maize weevil, and $S$. granarius, the grain weevil, have never been observed to survive on these legumes. Cotton (1920) noticed that Sitophilus adults could be found feeding on various fruits and that larvae could develop on chickpeas (Cicer arietinum). Vayssière (1943) described severe damage by $S$. oryzae to split peas and lentils. These breeding abilities on legume seeds were confirmed by Coombs et al. (1977) and Holloway (1986). More recent studies have confirmed that the alimentary spectrum of these cereal weevils

\footnotetext{
*Correspondence. E-mail: agrenier@jouy.inra.fr.
}

contains species belonging to the families Fabaceae, Caesalpiniaceae, Chenopodiaceae, Clusiaceae and Fagaceae (Delobel \& Tran, 1993). Weevils could even show higher efficiencies on chestnuts and acorns than on wheat (Delobel \& Grenier, 1993).

Genetical analyses of the ability to feed and breed on split peas, using crosses between pea-breeding and non-pea-breeding strains, led to inconsistent conclusions. Thind \& Muggleton (1981) showed that this character was controlled by only a single autosomal gene in a strain from Trinidad, but other factors (such as a sex-linked lethal gene) might act in addition to this autosomal gene in another strain from Africa. The results obtained by Holloway \& Smith (1985) were not consistent with a simple Mendelian mode of inheritance, but might implicate a maternal factor, such as a symbiont. Therefore, the genetic background of the pea-breeding ability remained to be clarified in these cereal weevils, as well as the possible intervention of their intracellular symbionts located in larval and ovarian bacteriomes (Nardon, 1971; Nardon \& Wicker, 1981). 


\section{Materials and methods}

\section{Culture of Sitophilus strains}

In the laboratory, weevils were maintained for several years on wheat at $27.5^{\circ} \mathrm{C}$ and 70 per cent relative humidity (r.h.) in plastic latticed boxes kept in a climatic cabinet, according to Laviolette \& Nardon (1963). After screening for pea-breeding ability among numerous strains available in the laboratory (54 strains coming from all over the world), four $S$. oryzae strains were selected which had some individuals able to feed and achieve their complete development on peas (Delobel \& Grenier 1993). These strains were thereafter kept on split peas of commercial origin (Vivien Paille), to maintain the selection pressure. In our experiments on pea resistance, we used the pea-resistant strain from China which had the highest ratio of resistant individuals at the beginning of the selection (12.5 per cent; 36 pea-feeding adults out of 289). This strain was maintained for 24 generations on peas before the experiment. The non-pea-breeding population came from a reference strain (SFr) studied in our laboratory for more than 25 years.

\section{Genetical experiments and tests of pea resistance}

in S. oryzae

In $S$. oryzae, reciprocal crosses between the pearesistant strain (China) and the pea-susceptible strain (SFr) were conducted on wheat, in order to obtain both pea-resistant and pea-susceptible progenies. Each mating was individually effected by isolating a virgin pair in a plastic tube, and allowing the female to lay eggs on wheat kernels for 2 weeks. Genetical studies were conducted on pairs: (i) in each parental cross (control); (ii) in the two reciprocal $F_{1}$ hybrids (one between a Chinese female and an SFr male: the CS cross; and the other between an SFr female and a Chinese male: the SC cross); (iii) in $F_{2}$ hybrids coming from the progeny of $F_{1}$ hybrids but maintained in separate tubes; and (iv) in backcrosses between $F_{1}$ hybrids and each parent. About 1 month after egg laying, the progeny of each pair emerged from the wheat kernels. Tests of resistance were effected by maintaining adults (about 15 day-old) on split peas for 14 days. This time was sufficient to observe the ability of weevils to survive on this legume. In previous experiments, Delobel \& Grenier (1993) confirmed that when adults were able to feed for 14 days on split peas, the complete development from egg to adult was always observed on these seeds.
Pea varieties and dose-response mortality of $\mathrm{S}$. oryzae

Pea strains, both commercial and noncommercial, were provided by the Station d'Amélioration des Plantes (INRA, Versailles, France) as untreated seeds. As many as 31 different varieties of split peas were tested for the dose-response mortality of $S$. oryzae adults. When necessary, seeds were powdered in a blender and bolted through a $0.2 \mathrm{~mm}$ screen. Yellow split-pea and wheat flours were mixed together in various proportions $(0,2.5,5,10,20,40$, 60 and 80 per cent pea by weight) and presented to insects as reconstituted pellets by adding water, according to Holloway's method (1986). Pellets were allowed to dry overnight before experiments. For each dose, 30 adults from the sensitive strain $\mathrm{SFr}$ were put on pellets and dead insects were observed each day, until 95 per cent mortality in the most concentrated sample occurred, and the $\mathrm{LC}_{50}$ (concentration required to kill 50 per cent of individuals) was calculated for each pea variety. The appearance of the seed was also observed. It could be smooth ( $l=$ 'lisse') or wrinkled ( $r$ or $r b=$ 'ridé'), $r$ and $r b$ seeds differing in their starch composition.

\section{Aposymbiotic populations}

In order to test the possible intervention of intracellular symbionts in the mechanism of detoxification, an aposymbiotic population was obtained from the normally symbiotic Chinese strain by heat treatment $\left(35^{\circ} \mathrm{C}\right.$ for 3 weeks; Nardon, 1973). The doseresponse curve to pea supplementation in the food was studied both in aposymbiotic and in normally symbiotic populations of the resistant strain (China), and the non-pea-breeding strain (SFr) was used as control.

\section{Statistical tests}

Classical $\chi^{2}$-tests for comparison of distributions and the $t$-test for comparison of proportions were used to analyse results. The dose-response curves of mortality of the weevil on different varieties of pea or in the presence or absence of symbionts were obtained using the program Toxicologie (Febvay \& Rahbé, 1991). This program used the probit transformation of a sigmoid curve of mortality and calculated the equation of the regression curve as well as the $\mathrm{LC}_{50}$ for each pea variety. 


\section{Results}

\section{Genetical analysis of the ability to breed on whole split peas in the rice weevil}

Adults were tested on whole yellow split peas commercialized by Vivien Paille (Valenciennes, France). Results are given in Table 1. In parental populations, as expected, the progeny derived from pea-breeding Chinese weevils were pea-resistant (R) and the progeny from non-pea-breeding weevils were pea-susceptible (S).

The total $F_{1}$ hybrid progeny from 65 pairs was mainly pea-susceptible (only 3.05 per cent resistant). If we consider reciprocal hybrids: 1.50 per cent of offspring of CS crosses (China female $\times$ SFr male) were resistant and 4.89 per cent of offspring of SC crosses (SFr female $\times$ China male) were resistant. By studying individual pairs, it was possible to separate two kinds of hybrid progeny in each reciprocal cross. In CS crosses, 30 pairs out of 31 gave only $S$ individuals, but one pair furnished a mixed progeny with about half $\mathrm{R}$ and half $\mathrm{S}$ adults (56 per cent resistant). In SC crosses, 30 pairs out of 34 gave only $S$ adults, but three pairs furnished a mixed progeny (51.5 per cent resistant) and one pair gave a weaker resistance ( 9 per cent resistant) (this last pair is not analysed in Table 1). In our case, heterozygosity $\chi^{2}$ could not be calculated because it was impossible to distinguish heterozygous individuals from homozygous ones, in the sensitive population.
In the $F_{2}$ generation, the total progeny issuing from $F_{1}$ hybrids was 19.61 per cent resistant with 17.57 per cent resistant in CS crosses and 21.51 per cent resistant in SC crosses, respectively. However, by considering $\mathrm{F}_{2}$ progeny according to the previous classification of $F_{1}$ generations, we could observe that in $F_{2}$ progeny coming from 100 per cent susceptible $F_{1}$ hybrids, we obtained 18.18 per cent resistant insects (17.39 per cent resistant in CS and 18.97 per cent resistant in SC). By contrast, if we consider the $F_{2}$ progeny coming from mixed $F_{1}$ hybrids we obtained 45.42 per cent resistant insects ( 32 per cent resistant in CS and 48.05 per cent resistant in SC).

From the analysis of $F_{1}$ hybrids, it appeared that the pea-resistant character was not expressed in the $F_{1}$ generation and might be recessive. Moreover, the two reciprocal crosses gave nearly similar progenies, therefore this character did not seem to be sex-linked. If we suppose that the resistant character was controlled by a single recessive gene, the existence of a mixed $F_{1}$ progeny in four pairs $(52.33$ per cent resistant) could be explained by the occurrence of heterozygous adults in the pea-susceptible parental population ( $\mathrm{SFr}$ ). If so, this $\mathrm{F}_{1}$ progeny should contain half homozygous resistant insects and half susceptible heterozygous ones. This hypothesis was confirmed because no significant difference occurred when comparing observed proportions to the theoretical values $\frac{1}{2}: \frac{1}{2}\left(\chi_{1}^{2}=0.42\right)$.

In the $\mathrm{F}_{2}$ generation, progenies from both recipro-

Table 1 Inheritance of pea resistance in Sitophilus oryzae fed on whole split peas

\begin{tabular}{llccccc}
\hline Generation & $\begin{array}{l}\text { Type of mating } \\
(\text { female } \times \text { male) }\end{array}$ & $\begin{array}{c}\text { No. of } \\
\text { pairs }\end{array}$ & $\begin{array}{c}\text { Observed } \\
\text { R:S progeny }\end{array}$ & $\begin{array}{c}\text { Observed } \\
\text { R \% }\end{array}$ & $\begin{array}{c}\text { Expected } \\
\text { R \% } \dagger\end{array}$ & $\chi^{2}$-test \\
\hline Parents & China $\times$ China & 14 & $861: 0$ & 100 & 100 & - \\
& SFr $\times$ SFr & 15 & $0: 1449$ & 0 & 0 & - \\
$F_{1}$ CS & China $\times$ SFr (total) & 31 & $29: 1901$ & 1.50 & 0 & - \\
& From 100\% S progeny & 30 & $1: 1879$ & 0.05 & 0 & 0.72 NS \\
& From 50\% R: 50\% S progeny & 1 & $28: 22$ & 56 & 50 & - \\
$F_{1}$ SC & SFr $\times$ China (total) & 34 & $79: 1535$ & 4.89 & 0 & - \\
& From 100\% S progeny & 30 & $0: 1404$ & 0 & 0 & 0.06 NS \\
& From 50\% R: 50\% S progeny & 3 & $73: 70$ & 51.05 & 50 & 121.65 \\
$F_{2}(\mathrm{CS})^{2}$ & CS $\times$ CS (total) & 31 & $726: 3406$ & 17.57 & 25 & 125.96 \\
& From 100\% S F progeny & 30 & $710: 3372$ & 17.39 & 25 & 6.48 \\
& From 50\% R: 50\% S F progeny & 1 & $16: 34$ & 32 & 56.25 & 28.58 \\
$F_{2}(\mathrm{SC})^{2}$ & SC $\times$ SC (total) & 34 & $949: 3461$ & 21.51 & 25 & 77.91 \\
& From 100\% S F progeny & 30 & $762: 3255$ & 18.97 & 25 & $0.39 \mathrm{NS}$ \\
\hline
\end{tabular}

C, China; S, SFr. Reciprocal crosses were effected between resistant (China) and susceptible (SFr) strains and studied in $F_{1}$ and $F_{2}$ generations.

$\dagger$ Expected R\% from the hypothesis of recessive autosomal inheritance.

NS, observed and expected proportions were not signficantly different at the $5 \%$ level $\left(\chi_{1}^{2}=3.84\right)$.

(C) The Genetical Society of Great Britain, Heredity, 79, 15-23. 
cal crosses using 100 per cent susceptible $F_{1}$ hybrids were not significantly different from each other $\left(\chi_{1}^{2}=3.38\right)$. However, all $\chi^{2}$ tests were inconsistent with the hypothesis of a recessive gene with segregation of characters in the $\mathrm{F}_{2}$ generation, according to theoretical values $\frac{1}{4} \mathrm{R}: \frac{3}{4} \mathrm{~s}$ the observed numbers of resistant weevils were all lower than expected, because of the very high toxicity of the pea variety used in this experiment.

Nevertheless, in the $F_{2}$ generation, the results obtained from mixed $\mathrm{F}_{1}$ hybrids were significantly different from those obtained from 100 per cent susceptible $F_{1}$ progeny $\left(\chi_{1}^{2}=202.62\right)$ and gave proportions closer to $9 / 16 \mathrm{R}: 7 / 16 \mathrm{~S}$, as expected in such crosses $\left(\chi_{1}^{2}=14.57\right)$; however, these results also were affected by an increase in pea toxicity.

\section{Measurements of $L C_{50}$ of different pea varieties on} S. oryzae survival

The excess of susceptible insects observed in the first genetical analysis was apparently correlated with an increase in the toxicity of the new pea seeds (Vivien Paille) used in this experiment. Therefore, we tested as many as 31 pea varieties for their toxicity on the rice weevil.

First we calculated the dose-response mortality curve and $\mathrm{LC}_{50}$ for each variety by using 30 adults of the sensitive strain in $0-80$ per cent pea pellets. For 4 days exposure on all varieties, most of the weevils died at higher concentrations and for 6 days exposure most of the weevils were killed, even at lower pea doses. Therefore, we calculated the $\mathrm{LC}_{50}$ for each pea variety for 4 days exposure and classified peas according to their decreasing toxicity (Table 2). For example, the Colmo variety was the most toxic with an $\mathrm{LC}_{50}$ of about 7 per cent, whereas the 829 variety was the least toxic with an $\mathrm{LC}_{50}$ of about 200 per cent (i. e. about only 50 per cent weevils died at higher pea concentrations in the pellets). The pea variety used in the previous genetical analyses was classified in the group of intermediate toxicity $\left(\mathrm{LC}_{50}=60.93\right.$ per cent $)$, which did not explain the excess in toxicity with respect to Mendelian proportions.

Secondly, we tested the mortality of the resistant weevil strain from China by exposing 30 adults for 14 days on whole split peas from these 31 varieties. Surprisingly, there was no correlation between $\mathrm{LC}_{50}$ on pellets for the sensitive strain and mortality percentages for a 14 days exposure of the resistant strain. The pea variety currently used in the laboratory (because available in large quantity and with perenniality) was the most toxic for weevils and some varieties with a high $\mathrm{LC}_{50}$ (low toxicity) could lead to 50 per cent mortality for the resistant strain. The lethal effect of pea seemed to be correlated with the phenotype of the grain (smooth or wrinkled) which was itself correlated with a difference in starch quality. Therefore, a high mortality was observed on $r$ or $r b$ seeds (increased hardness) rather than on $l$ smooth seeds which were softer, independently of the pea allelochemicals composition.

In conclusion, in order to obtain a better genetical analysis by avoiding an artificial increase in mortality caused by the hardness of the seed, we chose to use pellets with a pea concentration which was lethal for the susceptible strain but not for the resistant strain, in place of whole seeds. Standard curves of mortality in both populations on mixed pellets showed that 60 per cent pea pellets was a concentration which was sufficient to kill susceptible weevils without affecting the survival of resistant ones.

\section{Genetical analysis for weevil ability to survive on 60 per cent pea-40 per cent wheat pellets}

Comparable crosses to those in the first experiment were conducted on 60 per cent pea pellets, as defined in the previous section. Results are shown in Tables $3 \mathrm{a}$ and $3 \mathrm{~b}$. As expected, when Chinese weevils were intercrossed the progeny was entirely pea-resistant (R) $(n=468)$, and when SFr weevils were intercrossed the progeny was completely pea-susceptible $(\mathrm{S})(n=280)$. The total $\mathrm{F}_{1}$ hybrid progeny from 60 pairs was nearly completely pea-susceptible (only 0.004 per cent resistant; $n=2284$ ) and no difference appeared between reciprocal hybrid CS and SC crosses, as in the case of a recessive gene which is not sex-linked.

In the $F_{2}$ generation, the total progeny of $F_{1}$ hybrids was 25.32 per cent resistant with, respectively, 25.97 per cent resistant in CS crosses and 24.11 per cent resistant in SC crosses. These results did not differ significantly from the segregation of characters of a recessive gene in the $F_{2}$ generation. Observed values for both crosses and total progeny were tested with the expected values $\frac{3}{4}: \frac{1}{4}$ and $\chi^{2}$-values were in agreement with this hypothesis.

In order to perform the genetical analysis we also studied reciprocal back-crosses (BC) between each hybrid (CS and SC) and each parent (resistant or susceptible). Results are shown in Table 3b. When a hybrid (female or male) was mated with the susceptible parent, all its progeny was susceptible, whereas when it was mated with the resistant parent, its progeny was half resistant : half susceptible. In this 
Table 2 Comparison of the toxicity of the different varieties of pea for Sitophilus oryzae adults

\begin{tabular}{|c|c|c|c|c|}
\hline Pea variety & $\begin{array}{c}\operatorname{LC}_{50}(4 \mathrm{~d}) \\
\text { test of SFr on } \\
0-80 \% \text { pea pellets }\end{array}$ & $\begin{array}{l}\% \text { mortality }(14 \mathrm{~d}) \\
\text { test of China } \\
\text { on whole split pea }\end{array}$ & $\begin{array}{l}\text { Pea variety: } \\
\text { Winter (W) } \\
\text { Spring (Sp) }\end{array}$ & $\begin{array}{l}\text { Seed aspect: gene } \\
\text { 'ridé' }(r, r b) \\
\text { or 'lisse' }(l)\end{array}$ \\
\hline Colmo & 6.96 & 6.67 & $\mathrm{Sp}$ & $l$ \\
\hline Bingo & 7.15 & 3.33 & - & $l$ \\
\hline Countess & 8.02 & 0 & - & $x$ \\
\hline Stampede & 10.17 & 23.33 & - & $x$ \\
\hline Diabolo & 11.07 & 0 & $\mathrm{Sp}$ & $l$ \\
\hline Solara & 11.17 & 0 & $\mathrm{Sp}$ & $l$ \\
\hline Figaro & 11.59 & 3.33 & - & $l$ \\
\hline Micro & 14.44 & 46.67 & - & $r$ \\
\hline Finale & 14.50 & 3.33 & $\mathrm{Sp}$ & $l$ \\
\hline 776 & 15.27 & 3.33 & - & $l$ \\
\hline Amac & 15.89 & 0 & W & $l$ \\
\hline 777 & 16.00 & 0 & - & $l$ \\
\hline Mini & 18.44 & 13.33 & - & $r$ \\
\hline Amino & 23.29 & 6.67 & $\mathrm{Sp}$ & $l$ \\
\hline Aldot & 26.11 & 0 & - & $l$ \\
\hline Terese & 26.71 & 0 & $\mathrm{Sp}$ & $l$ \\
\hline Progretta & 27.10 & 0 & $\mathrm{Sp}$ & $x$ \\
\hline Alfi & 27.89 & 13.33 & - & $r$ \\
\hline Madria & 28.72 & 0 & $\mathrm{Sp}$ & $l$ \\
\hline 667 & 28.98 & 40.00 & - & $r b$ \\
\hline Alaska Sweet & 29.14 & 0 & $\mathrm{Sp}$ & $r b$ \\
\hline Frilene & 29.32 & 6.67 & W & $l$ \\
\hline Frogel & 38.96 & 13.33 & W & $r$ \\
\hline Frisson & 40.29 & 0 & W & $l$ \\
\hline Lab. pea strain & 60.93 & 76.67 & - & $x$ \\
\hline Cennia & 61.65 & 16.67 & - & $r b$ \\
\hline Frigloo & 67.20 & 3.33 & W & $l$ \\
\hline 206 & 81.67 & 0 & W & $l$ \\
\hline Rafale & 83.85 & 3.33 & W & $l$ \\
\hline 831 & $141.68^{*}$ & 50.00 & - & $r b$ \\
\hline 829 & $198.26^{*}$ & 26.67 & - & $r b$ \\
\hline
\end{tabular}

The susceptible weevil strain (SFr) was tested on pellets and toxicity expressed as 50 per cent lethal concentration at day 4. The resistant weevil strain (China) was tested on whole split peas and toxicity expressed as adult mortality percentage for a 14 day exposure. Some characteristics of pea varieties and seed appearance are also reported. $x=$ unknown.

*Extrapolated values.

latter case, $\chi^{2}$-test values did not differ significantly from the ratio $\frac{1}{2}: \frac{1}{2}$ for both total reciprocal progenies, as expected for the hypothesis of a recessive and autosomal inheritance of the resistant character.

This new genetical analysis on $\mathrm{F}_{1}, \mathrm{~F}_{2}$ and $\mathrm{BC}$ was fully in agreement with the hypothesis of Mendelian heredity of resistance to pea in Sitophilus oryzae caused by only one recessive autosomal gene.

Moreover, in order to know if one sex was more affected than the other by pea resistance, we observed the sex ratio in both resistant and susceptible progenies in $F_{2}$ generations and resistant backcrosses (Table 4). For each mating, the ratio of females was determined. This ratio was similar between susceptible and resistant progenies $(t$-tests showed no significant differences). In each progeny, females and males were identically affected by toxicity. However, differences in female ratios between two crosses appeared, but will not be discussed in this paper.

\section{Possible effects of symbionts}

In a previous assay we observed that when aposymbiotic adults (produced by heat-treatment from the pea-resistant strain) were put on whole yellow split peas for 14 days, the mortality ratio was 53.33 per cent $(n=90)$. Subsequently, the dose-response mortality curve to pea supplementation in food was studied, both in aposymbiotic and in normally 
Table 3a Analysis of the inheritance of the ability to feed on pea pellets (60\% pea) in Sitophilus oryzae studied in parental, $F_{1}$ and $F_{2}$ generations

\begin{tabular}{|c|c|c|c|c|c|c|}
\hline Generation & $\begin{array}{l}\text { Type of mating } \\
(\text { female } \times \text { male })\end{array}$ & $\begin{array}{l}\text { No. of } \\
\text { pairs }\end{array}$ & $\begin{array}{l}\text { Observed } \\
\mathrm{R}: \mathrm{S} \text { values }\end{array}$ & $\begin{array}{c}\text { Observed } \\
\text { R \% }\end{array}$ & $\begin{array}{c}\text { Expected } \\
\mathrm{R} \% \dagger\end{array}$ & $\chi^{2}$-test \\
\hline Parents & $\begin{array}{l}\text { China } \times \text { China } \\
\text { SFr } \times \text { SFr }\end{array}$ & $\begin{array}{l}10 \\
10\end{array}$ & $\begin{array}{l}468: 0 \\
0: 280\end{array}$ & $\begin{array}{r}100 \\
0\end{array}$ & $\begin{array}{r}100 \\
0\end{array}$ & - \\
\hline $\begin{array}{r}F_{1} \text { CS } \\
\text { SC }\end{array}$ & $\begin{array}{l}\text { China } \times \text { SFr } \\
\text { SFr } \times \text { China } \\
\text { Total CS }+ \text { SC }\end{array}$ & $\begin{array}{l}30 \\
30 \\
60\end{array}$ & $\begin{array}{l}6: 1642 \\
3: 633 \\
9: 2275\end{array}$ & $\begin{array}{l}0.004 \\
0.005 \\
0.004\end{array}$ & $\begin{array}{l}0 \\
0 \\
0\end{array}$ & $\begin{array}{l}- \\
- \\
-\end{array}$ \\
\hline $\begin{array}{l}\mathrm{F}_{2}(\mathrm{CS})^{2} \\
\quad(\mathrm{SC})^{2}\end{array}$ & $\begin{array}{l}\mathrm{CS} \times \mathrm{CS} \\
\mathrm{SC} \times \mathrm{SC} \\
\text { Total }(\mathrm{CS})^{2}+(\mathrm{SC})^{2}\end{array}$ & $\begin{array}{l}30 \\
30 \\
60\end{array}$ & $\begin{array}{c}1086: 3095 \\
528: 1662 \\
1613: 4758\end{array}$ & $\begin{array}{l}25.97 \\
24.11 \\
25.32\end{array}$ & $\begin{array}{l}25 \\
25 \\
25\end{array}$ & $\begin{array}{l}2.12 \mathrm{NS} \\
0.93 \mathrm{NS} \\
0.34 \mathrm{NS}\end{array}$ \\
\hline
\end{tabular}

Abbreviations and symbols have the same meaning as in Table 1.

Table $3 \mathbf{b}$ Analysis of the inheritance of the ability to feed on pea pellets (60\% pea) in reciprocal back-crosses in Sitophilus oryzae

\begin{tabular}{|c|c|c|c|c|c|c|}
\hline & $\begin{array}{l}\text { Type of mating } \\
(\text { female } \times \text { male })\end{array}$ & $\begin{array}{l}\text { No. of } \\
\text { pairs }\end{array}$ & $\begin{array}{l}\text { Observed } \\
\mathrm{R}: S \text { values }\end{array}$ & $\begin{array}{c}\text { Observed } \\
\mathrm{R} \%\end{array}$ & $\begin{array}{c}\text { Expected } \\
\mathrm{R} \% \dagger\end{array}$ & $\chi^{2}$-test \\
\hline \multirow[t]{5}{*}{ Backcross CS } & $\mathrm{CS} \times \mathrm{SFr}$ & 27 & $6: 2081$ & 0.003 & 0 & - \\
\hline & $\mathrm{CS} \times$ China & 26 & $1063: 963$ & 52.47 & 50 & 4.94 \\
\hline & $\mathrm{SFr} \times \mathrm{CS}$ & 18 & $0: 922$ & 0 & 0 & - \\
\hline & China $\times$ CS & 13 & $400: 404$ & 49.75 & 50 & $0.02 \mathrm{NS}$ \\
\hline & Total resistant progeny CS & 39 & $1463: 1367$ & 51.70 & 50 & $3.26 \mathrm{NS}$ \\
\hline \multirow[t]{5}{*}{ Backcross SC } & $\mathrm{SC} \times \mathrm{SFr}$ & 16 & $0: 1377$ & 0 & 0 & - \\
\hline & $\mathrm{SC} \times$ China & 17 & $269: 251$ & 51.73 & 50 & $0.62 \mathrm{NS}$ \\
\hline & $\mathrm{SFr} \times \mathrm{SC}$ & 19 & 5:1499 & 0.003 & 0 & - \\
\hline & China $\times \mathrm{SC}$ & 20 & 533:608 & 46.71 & 50 & 4.93 \\
\hline & Total resistant progeny SC & 37 & $802: 859$ & 48.28 & 50 & $1.96 \mathrm{NS}$ \\
\hline Both $B C$ & Total resistant progeny $B C$ & 76 & $2265: 2226$ & 50.43 & 50 & $0.34 \mathrm{NS}$ \\
\hline
\end{tabular}

$\mathrm{BC}$, back-cross. On the last line, progenies of both back-crosses (CS and SC) showing resistant individuals were pooled (76 pairs). Other abbreviations and the symbols have the same meaning as in Table 1.

symbiotic populations. In each population, 30 individuals for each pea concentration were tested. For a 6-day exposure, as expected, the symbiotic sensitive population exhibited a high level of mortality at pea concentrations as low as 10 per cent (Fig. 1), whereas the symbiotic resistant population from China was not affected. Aposymbiotic Chinese weevils did not die below 60 per cent pea concentration but they became sensitive for higher concentrations. Their $\mathrm{LC}_{50}$ was high, 97.54 vs. 11.54 for the sensitive population $\left(\mathrm{LC}_{50}\right.$ of the symbiotic China strain was close to infinite).

\section{Discussion and conclusion}

\section{Ability to breed on split peas}

The evolution of the ability to feed and breed on peas seems to have occurred recently in cereal weevils (Coombs et al., 1977; Pemberton \& de Rodriguez, 1981). The great barriers to feeding on legumes which $S$. oryzae needs to overcome are the toxicants present in most Leguminosae which contain a wide range of phytotoxins with an insecticidal function (Harbone, 1982). Adaptation processes of herbivorous insects to deleterious plant allelochemicals include various strategies such as sequestration, target site insensitivity, occurrence of surfactants and/or an alkaline $\mathrm{pH}$ in the gut, differential absorption by the peritrophic membrane, induction of detoxifying enzymes, and excretion (Slansky, 1992).

Nonlegume feeding adult $S$. oryzae die on yellow split peas because of intake of toxins, rather than through the effects of antifeedants (Holloway, 1986). This author also found that rice weevils fed on peas had enhanced adult survival and reproduction after 
Table 4 Comparison of distributions of females and males in $F_{2}$ and back-cross progeny of Sitophilus oryzae

\begin{tabular}{cllccc}
\hline & $\begin{array}{l}\text { Type of matings } \\
(\text { female } \times \text { male })\end{array}$ & $\begin{array}{l}\text { S or R } \\
\text { character }\end{array}$ & $\begin{array}{c}\text { No. of } \\
\text { progeny }\end{array}$ & Female $\%$ & $t$-test \% \\
\hline $\mathrm{F}_{2}(\mathrm{CS})^{2}$ & CS $\times \mathrm{CS}$ & Susceptible & 3092 & 61.48 & $0.680 \mathrm{NS}$ \\
& & Resistant & 1086 & 60.31 & \\
$(\mathrm{SC})^{2}$ & SC $\times \mathrm{SC}$ & Susceptible & 1662 & 49.16 & $0.261 \mathrm{NS}$ \\
& & Resistant & 528 & 49.81 & \\
Back-cross & CS $\times$ China & Susceptible & 959 & 47.13 & \multirow{2}{*}{$0.759 \mathrm{NS}$} \\
& & Resistant & 1061 & 48.82 & \\
& China $\times \mathrm{CS}$ & Susceptible & 401 & 53.12 & \multirow{2}{*}{$0.094 \mathrm{NS}$} \\
& & Resistant & 406 & 53.45 & \\
\hline
\end{tabular}

Susceptible and resistant progeny were considered separately. Symbols have the same meaning as in Table 1. Observed and expected proportions were not significantly different at the $5 \%$ level.

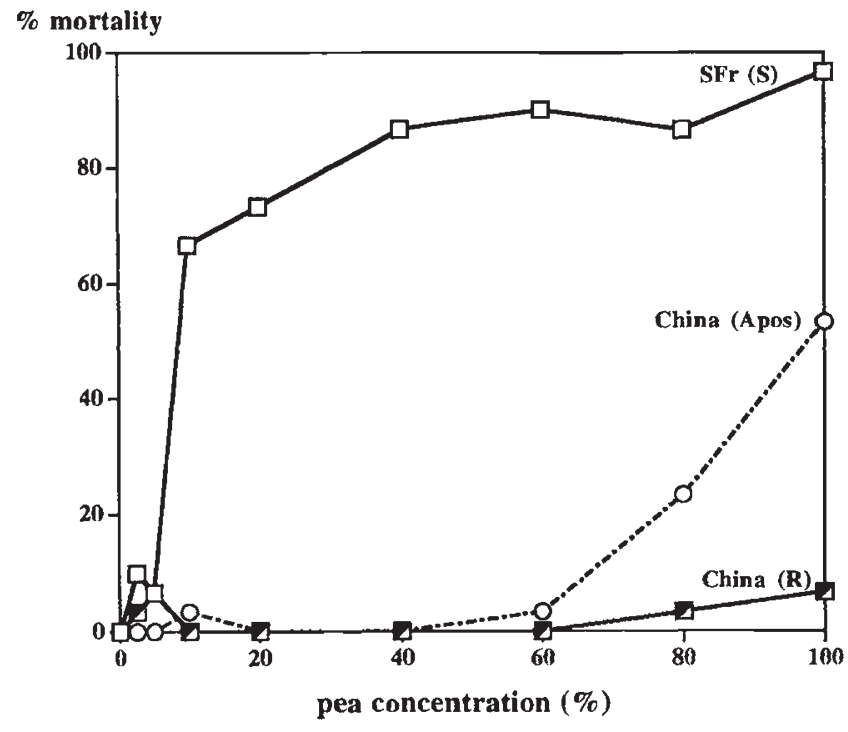

Fig. 1 Dose-response mortality curve at 6 days for Sitophilus oryzae feeding on pea/wheat pellets, studied in the susceptible strain (SFr) and in the resistant strain (China). The mortality of the aposymbiotic resistant strain (Apos) obtained from the China strain is represented by the interrupted line.

removal from the legume. This may be indirect evidence for an allelochemical-induced beneficial enzyme system(s) in this species. By studying enzyme activities, Baker \& Woo (1992) showed that despite a small decrease in $\beta$-glucosidase activity in the gut of pea-breeding weevils when transferred to wheat, there was no obvious relationship between $\beta$-glucosidase activity in adults and their adaptation to feeding and breeding on legumes.
Holloway \& Mackness (1988) described mechanisms of detoxification of legume secondary compounds in legume-feeding $S$. oryzae. They studied pea-resistant and susceptible weevil strains (only breeding on wheat) on six legume seeds: adzuki bean (Vigna angularis), split pea (Pisum sativum), brown lentil (Lens esculenta), cowpea (Phaseolus vulgaris), green gram (Vigna radiata) and soybean (Glycine max). Wheat-breeding populations survived very poorly on legumes, whereas the legume-breeding populations survived better. Soybean was clearly more toxic than the five other legumes.

\section{Genetical analysis of the pea-breeding character}

From the genetical analysis conducted in our study, it can be concluded that only one autosomal recessive gene is involved in the expression of pea resistance in $S$. oryzae. Resistant populations able to develop on peas are homozygous for the recessive gene. Selection of weevils on pea seeds has led to a population (China) which is completely resistant to peas. Even if this population is bred thereafter on wheat from egg to adult, weevils remained fully resistant to peas.

It can be noted that in the first experiment, the progeny of some crosses between Chinese resistant and SFr susceptible strains was half resistant and half susceptible, showing that the susceptible SFr population may contain some individuals ( 5 out of $65=7.69$ per cent) which were heterozygous for the resistant gene. In order to estimate the frequency of this gene in the SFr strain we maintained a large 
number of adults (about 4000) on peas and we found only five insects alive after 2 weeks. The proportion of homozygous resistant weevils in $\mathrm{SFr}$ was then 0.13 per cent leading to an estimate of the resistance frequency, $p_{\text {res, }}$, of 0.0354 in this population. The theoretical proportion of heterozygous weevils could be calculated ( 6.83 per cent) and this value was very similar to that observed in the experiment ( 7.69 per cent).

The demonstration of the possible occurrence of heterozygous insects in susceptible populations allows us to discuss previous conclusions dealing with genetical transmission of the ability of $S$. oryzae to feed on peas. Holloway \& Smith (1985) compared survival of $S$. oryzae adults after 14 days on yellow split peas, in two resistant populations (Trinidad and Tanzania) and a susceptible one (India). In $F_{1}$ hybrids among these three strains, they noticed important deviations from expected Mendelian monogenic frequencies. Especially, reciprocal hybrids obtained with the susceptible Indian strain showed a significant level of resistance. In fact, an analysis of their data, considering that none of the population was homozygous for the studied character, showed that in the Trinidad strain, depending of the data used, about 1 per cent of weevils were homozygous for pea susceptibility, and up to 6 per cent were homozygous in the Tanzania strain. In the reverse situation, the Indian population contained 4 per cent of resistant homozygous insects, which implies that 33 per cent were heterozygous. These calculated values allow the interpretation of all the results of crossing experiments between the three strains, especially the unexpected high ratio of surviving insects observed in the cross containing the Indian strain, and also the high ratio of susceptible insects in the crosses between Tanzania and Trinidad lines (14.2 per cent). Therefore, the results of Holloway \& Smith (1985) are not contradictory to those of Thind \& Muggleton (1981), and like ours point to a resistance borne by a single recessive autosomal gene.

\section{Toxicity levels in peas}

The analysis of mortality of the sensitive strain at day 4 on ground peas, showed a wide range of variation in the content of the toxic subsiances $\left(\mathrm{LC}_{50}\right.$ between 7 and 200). Winter peas appeared to be less toxic than spring peas.

On whole seeds, the mortality of the pea-feeding population was nil or nearly nil for 77 per cent of the pea strains. Most of the pea strains which appeared to be resistant to weevil attack were of the wrinkled phenotype $(r$ or $r b)$. In peas, the $r$ and $r b$ loci are known to encode genes affecting the starch biosynthetic pathway by modifying the crystalline structure of starch granules and their contents in amylopectin (Bogracheva et al., 1995; Lloyd et al., 1996). The presence of a special starch can modify the physical resistance of the seeds, either by enhancing hardness or lowering the water content in the same conditions. The action of other secondary compounds could not be excluded, although these compounds should also have acted on the sensitive strain, even after grinding.

\section{Relationships between detoxification and symbiosis}

In the rice weevil, the aposymbiotic population obtained from the pea-resistant strain by heat treatment was resistant for pea concentrations up to 60 per cent. From this result, it may be concluded that resistance to pea is not linked to symbiosis. However, at higher concentrations, mortality appears, which reduces the ability to feed and breed on peas.

The effect of symbionts may be either direct caused by their own action in detoxification (as shown by Dowd $(1989,1992)$ in Lasioderma serricorne where symbiotic yeasts produced enzymes able to detoxify xenobiotics) or more probably indirect caused by their modifying the energy metabolism implicated in detoxification of allelochemicals. Indeed, it may be hypothesized that the loss of symbionts leading to modifications in the energy metabolism diminishing the oxidation capacities in the weevil (Heddi et al., 1993), could weaken the detoxification mechanisms in the aposymbiotic strains. This detoxification could be reduced not only in the case of the toxicity studied but also in the case of other allelochemicals present in peas.

In conclusion, the expression of pea resistance in S. oryzae is under the control of a single Mendelian autosomal recessive gene. Resistant populations able to develop on pea are homozygous for the recessive gene, but some wild susceptible populations can contain some heterozygous individuals. Symbionts are not directly required but might play a role in supplying disposable energy for the metabolism implicated in the detoxification of allelochemicals.

This study may be an illustration of how a minor genetical change can modify the pest status of an insect through an enlargement of its food adaptation. Thus $S$. oryzae, which is mainly a pest of cereals, may also be able to feed and breed on Legumes. 


\section{Acknowlegments}

We thank Dr R. Cousin (Génétique et Amélioration des Plantes, INRA, Versailles, France) for the supply of the pea varieties.

\section{References}

BAKER, J. E. AND woo, s. M. 1992. $\beta$-glucosidases in the rice weevil, Sitophilus oryzae: Purification, properties, and activity levels in wheat- and legume-feeding strains. Insect Biochem. Mol. Biol., 22, 495-504.

BOGRACHEVA, T. Y., DAVYDORA, N. I., GENIN, Y. U. AND HEDLEY, C. L. 1995. Mutant genes at the $r$ and $r b$ loci affect the structure and physico-chemical properties of pea seed starches. J. Exp. Bot., 46, 1905-1913.

COOMBS, C. W., BILlıINGs, C. J. AND PORTER, J. E. 1977. The effect of yellow split-peas (Pisum sativum L.) and other pulses on the productivity of certain strains of Sitophilus oryzae (L.) (Col. Curculionidae) and the ability of other strains to breed thereon. J. Stored Prod. Res., 13, 53-58.

COTTON, R. T. 1920. Tamarind pod-borer, Sitophilus linearis (Herbst.). J. Agric. Res., 20, 439-446.

DElobel, A. AND TRAN, M. 1993. In: Les Coléoptères des denrées alimentaires entreposées dans les régions chaudes, pp. 343-350. ORSTOM, Paris.

DELOBEL, B. AND GRENIER, A.-M. 1993. Effect of non-cereal food on cereal weevils and tamarind pod weevil (Coleoptera: Curculionidae). J. Stored Prod. Res., 29, 7-14.

DOWD, P. F. 1989. In situ production of hydrolytic detoxifying enzymes by symbiotic yeasts in the cigarette beetle (Coleoptera: Anobiidae). J. Econ. Entomol., 82, 396-400.

DowD, P. F. 1992. Insect fungal symbionts: a promising source of detoxifying enzymes. J. Indust. Microbiol., 9, $149-161$.

FEBVAY, G. AND RAHBE, Y. 1991. 'Toxicologie', un programme pour l'analyse des courbes de mortalité par la méthode des probits sur Macintosh. Cah. Techn. INRA, 27, 77-78.

HARBONE, J. B. 1982. Introduction to Ecological Biochemistry, 2nd edn. Academic Press, London.

HEDDI, A., LEFEBVRE, F. AND NARDON, P. 1993. Effect of endocytobiotic bacteria on mitochondrial enzymatic activities in the weevil Sitophilus oryzae (Coleoptera: Curculionidae). Insect Biochem. Molec. Biol., 23, 403-411.

HOLloway, G. J. 1986a. The potency and effect of phytotoxins within yellow split-pea (Pisum sativum) and adzuki bean (Vigna angularis) on survival and repro- ductive potential of Sitophilus oryzae (L.) (Coleoptera: Curculionidae). Bull. ent. Res., 76, 287-295.

HOLloway, G. J. 1986b. A theoretical examination of the classical theory of inheritance of insecticide resistance and the genetics of time to knockdown and dry body weight in Sitophilus oryzae (L.) (Coleoptera: Curculionidae). Bull. ent. Res., 76, 661-670.

Holloway, G. J. AND MACKNESS, M. 1. 1988. The evolutionary adaptation of enzyme systems in Sitophilus oryzae fed on toxic legumes. Entomologia exp. appl., 48, 165-172.

HOLLOWAY, G. J. AND SMITH, R. H. 1985. Inheritance of the ability of Sitophilus oryzae (L.) (Coleoptera: Curculionidae) to feed and breed on yellow split-pea (Pisum sativum). Bull. ent. Res., 75, 367-375.

LAVIOLETTE, P. AND NARDON, P. 1963. Action des rayons gamma du cobalt 60 sur la mortalité et la fertilité des adultes d'un charançon du riz. Bull. Biol. Fr. Belg., 97, 305-333.

LLOYD, J. R., WANG, T. L. AND HEDLEY, C. L. 1996. An analysis of seed development in Pisum sativum. 19. Effect of mutant alleles at the $r$ and $r b$ loci on starch grain size and on the content and composition of starch in developing pea seeds. J. Exp. Bot., 47, 171-180.

NARDON, P. 1971. Contribution à l'étude des symbiotes ovariens de Sitophilus sasakii: localisation, histochimie et ultrastructure chez la femelle adulte. C. r. Acad. Sci. D, 272, 2975-2978.

NARDON, P. 1973. Obtention d'une souche asymbiotique chez le charançon Sitophilus sasakii: différentes méthodes et comparaison avec la souche symbiotique d'origine. C. r. Acad. Sci. D, 277, 981-984.

NARDON, P. AND WICKER, c. 1981. La symbiose chez le genre Sitophilus (Coléoptère, Curculionide). Principaux aspects morphologiques, physiologiques et génétiques. Ann. Biol., 20, 327-373.

PEMBERTON, G. W. AND DE RODRIguez, A. 1981. The occurrence of a strain of Sitophilus oryzae (L.) (Col. Curculionidae) breeding in Portuguese kibbled carobs. J. Stored Prod. Res., 17, 37-38.

SLANSKY, F., JR. 1992. Allelochemical-nutrient interactions in herbivore nutritional ecology. In: Rosenthal, G. A. and Berenbaum, M. R. (eds) Herbivores: Their Interactions With Secondary Plant Metabolites, vol. II, Evolutionary and Ecological Processes, 2nd edn, pp. 135-174. Academic Press, New York.

THIND, B. B. AND MUGGLETON, J. 1981. Inheritance of the ability of strains of Sitophilus oryzae (L.) (Coleoptera: Curculionidae) to breed on split-pea (Pisum sativum). Bull. ent. Res., 71, 419-424.

VAyssière, M. P. 1943. Le charançon du riz et les légumes secs. C. r. Acad. Agr. Fr. 29, 449-450. 